\title{
MIECDZYNARODOWA POZYCJA INWESTYCYJNA NOWYCH KRAJÓW UNII EUROPEJSKIEJ - DOŚWIADCZENIA INTEGRACJI I KRYZYSU
}

\begin{abstract}
Streszczenie: Zagraniczne finansowanie gospodarki jest jednym z istotnych problemów poruszanych w debatach społecznych i ekonomicznych. Z jednej strony kraje transformacji systemowej, ze względu na niedobory akumulacji krajowej, zmuszone były finansować swój rozwój po części kapitałem zagranicznym; z drugiej - nadmierne zaangażowanie kapitału zagranicznego może zwiększać ryzyko gospodarcze oraz podatność kraju na kryzysy finansowe. Szczególnie ostatnie lata pokazały wrażliwość gospodarek Unii Europejskiej na szoki finansowe i uwypukliły potrzebę monitorowania skali ich nierównowagi zewnętrznej, w tym finansowej.

Celem artykułu jest określenie poziomu bezpieczeństwa finansowania gospodarek nowych krajów UE kapitałem ze źródeł zagranicznych. Analizę przeprowadzono w oparciu o wielkość i strukturę międzynarodowej pozycji inwestycyjnej oraz wskaźniki zadłużenia zagranicznego netto i brutto. Dla zachowania porównywalności danych badanie wykonano na podstawie danych pochodzących z bazy Eurostat. Zakres czasowy analizy (tj. lata 2004-2013) pozwolił zbadać zmiany, jakie zaszły w trakcie pierwszej dekady członkostwa w Unii, szczególnie te wywołane kryzysem finansowym.

Słowa kluczowe: międzynarodowa pozycja inwestycyjna, zadłużenie zagraniczne, nierównowagi zewnętrzne, nowe kraje Unii Europejskiej.
\end{abstract}

\section{WPROWADZENIE}

Proces transformacji i rozwoju krajów Europy Środkowo-Wschodniej trwający nieprzerwanie od ponad 20 lat, stopniowa liberalizacja przepływów kapitałowych, a także integracja z Unią Europejską znacząco wpłynęły na relacje finansowe gospodarek z zagranicą. Permanentne niedobory kapitału charakterystyczne dla początkowej fazy transformacji systemowej, wynikające m.in. z niedostatków krajowej akumulacji, w sferze prywatnej w znacznym stopniu uzupełniane były kapitałem zagranicznym napływającym głównie w postaci bezpośrednich inwestycji zagranicznych. Rozwój rynków finansowych, idący w parze z wyższymi stopami zwrotu, przyciągał z kolei zagranicznych inwestorów portfelowych. To wszystko spowodowało narastanie zadłużenia zagranicznego oraz sukcesywne zwiększanie ujemnej

* Uniwersytet Łódzki, Wydział Ekonomiczno-Socjologiczny, Katedra Międzynarodowych Stosunków Gospodarczych. 
wartości międzynarodowej pozycji inwestycyjnej. Dodatkowo należy pamiętać, że nie bez wpływu na powyższe zmienne pozostawało ujemne saldo obrotów bieżących (w tym przede wszystkim powszechna w badanych krajach przewaga importu nad eksportem), finansowane właśnie kapitałem zagranicznym.

Nadmierne zadłużenie na rynkach międzynarodowych może zwiększać ryzyko kryzysów i zaburzeń nie tylko w sferze finansowej, lecz także w obszarze realnej gospodarki. Dobitnie wskazują na to doświadczenia niedawnego kryzysu gospodarczego oraz podjęte przez państwa UE działania mające na celu przeciwdziałanie długotrwałym nierównowagom ekonomicznym. Wśród przyjętych w grudniu 2011 r. regulacji, zwanych potocznie ,sześciopakiem”, istotną rolę odgrywa monitoring wskaźników ostrożnościowych, wśród których znajduje się zarówno relacja międzynarodowej pozycji inwestycyjnej netto do PKB (w podstawowym katalogu), jak i zadłużenie zagraniczne (wśród wskaźników dodatkowych).

Akceptując konieczność zagranicznego finansowania tzw. gospodarek doganiających, należy zwrócić szczególną uwagę na strukturę tego finansowania. Dla zapewnienia stabilności rozwoju gospodarczego kluczowe znaczenie powinny mieć źródła długoterminowe, przede wszystkim o charakterze udziałowym, a nie dłużnym, ponieważ stanowią mniejsze obciążenie dla gospodarki w przyszłych okresach.

Celem artykułu jest prezentacja wyników badania skali oraz struktury zagranicznych obrotów finansowych (międzynarodowej pozycji inwestycyjnej i zadłużenia zagranicznego) krajów, które przystąpiły do Unii Europejskiej w 2004 r. oraz później. Są to w większości kraje Europy Środkowej i Wschodniej, dla których integracja ze strukturami UE była zwieńczeniem procesów transformacji. Badanie wykonano w oparciu o dane Eurostatu, uwzględniając lata 2004-2013. To dziesięciolecie obejmuje pierwsze doświadczenia nowych członków UE w ugrupowaniu, jak też zawirowania wywołane kryzysem finansowym.

Artykuł został podzielony na sześć części. Po wprowadzeniu, w części drugiej przybliżono pojęcia międzynarodowej pozycji inwestycyjnej i zadłużenia zagranicznego jako mierników zewnętrznej nierównowagi makroekonomicznej gospodarki. W trzeciej i czwartej zaprezentowano kolejno kształtowanie się międzynarodowej pozycji inwestycyjnej w ujęciu nominalnym i w relacji do PKB oraz jej strukturę w nowych krajach Unii Europejskiej. Część piąta poświęcona została kwestiom zadłużenia zagranicznego badanych krajów. Główne wnioski, a także sugestie odnośnie dalszych kierunków badań ujęto w podsumowaniu.

\section{MIĘDZYNARODOWA POZYCJA INWESTYCYJNA I ZADŁUŻENIE ZAGRANICZNE - UWAGI OGÓLNE}

Międzynarodowa pozycja inwestycyjna (MPI) oraz wartość zadłużenia zagranicznego są jednymi z podstawowych miar finansowej otwartości i integracji gospodarek (Kučerová 2009: 25-41; Lane, Milesi-Ferretti 2000: 1-33), pozwalają również 
ocenić poziom nierównowagi zewnętrznej kraju (Nakonieczna-Kisiel 2011: 90). MPI to zestawienie salda wszystkich transakcji finansowych dokonywanych pomiędzy rezydentami (tj. NBP, instytucjami rządowymi i samorządowymi, sektorem bankowym oraz pozostałymi podmiotami rynkowymi) i nierezydentami. W ujęciu brutto prezentuje stan zagranicznych aktywów i pasywów podmiotów krajowych na koniec danego roku ${ }^{1}$ (Międzynarodowa ... 2014: 4). Różnica pomiędzy nimi stanowi międzynarodową pozycję inwestycyjną netto i informuje o tym, czy dany kraj jest międzynarodowym wierzycielem, czy też dłużnikiem (Międzynarodowa... 2014: 4).

Podstawowe kategorie, które składają się na MPI, to:

- bezpośrednie inwestycje zagraniczne,

- inwestycje portfelowe,

- pochodne instrumenty finansowe,

- pozostałe inwestycje, tj. np. udzielone lub otrzymane kredyty handlowe, pozostałe kredyty i pożyczki, gotówka, rachunki bieżące, lokaty i depozyty oraz pozostałe należności i pasywa zagraniczne.

Dodatkowo stronę aktywów pozycji inwestycyjnej uzupełniają oficjalne zagraniczne aktywa rezerwowe występujące w formie złota monetarnego, SDR-ów, pozycji rezerwowej w MFW, należności w walutach wymienialnych i pozostałych należności.

MPI netto jest silnie związana z bilansem obrotów bieżących, gdyż bezpośrednio odzwierciedla jego saldo. Charakterystyczne dla krajów transformujących się zwiększenie deficytu handlowego powoduje konieczność wzrostu także pasywów zagranicznych, dzięki którym możliwe jest sfinansowanie zwiększonego importu, a to powoduje pogorszenie międzynarodowej pozycji inwestycyjnej.

Przepływy kapitałowe tworzące międzynarodową pozycję inwestycyjną kraju można podzielić według kryterium rodzaju dochodu, jaki uzyskuje wierzyciel w zamian za pożyczony kapitał. W tym przypadku można wyróżnić (Międzynarodowa... 2014: 27):

- transakcje o charakterze udziałowym, od których dłużnik nie musi płacić odsetek (związane z nabyciem udziałów w kapitale własnym przedsiębiorstwa, reinwestycje zysków, zakup udziałowych papierów wartościowych przez inwestorów portfelowych oraz transakcje instrumentami pochodnymi);

- transakcje o charakterze dłużnym, tzw. hot money (Bluedorn et al. 2013: 4), których wykorzystanie obciążone jest dodatkowym kosztem w postaci odsetek (pożyczki i kredyty, publiczne i prywatne instrumenty dłużne).

Kapitały własne i reinwestycje zysków stanowią mniej ryzykowne, bardziej stabilne formy finansowania zagranicznego. Większym obciążeniem finansowym dla gospodarki (w przyszłych okresach) są instrumenty dłużne, dlatego drugim powszechnie

${ }^{1}$ Wszelkie przepływy zwiększające stan należności nierezydentów wobec rezydentów odnotowywane są po stronie aktywów, a przepływy zwiększające zasób kapitału w kraju (zwiększające zobowiązania rezydentów wobec nierezydentów) - po stronie pasywów. 
wykorzystywanym miernikiem poziomu nierównowagi zewnętrznej jest zadłużenie zagraniczne. Jest to zestawienie tych pasywów wykazanych w pozycji inwestycyjnej, od których dłużnicy zobowiązani są płacić odsetki (Międzynarodowa... 2014: 5 , 27). Podobnie jak w przypadku MPI, zadłużenie zagraniczne przedstawia się w ujęciu brutto (zobowiązania rezydentów wobec nierezydentów) lub netto (zobowiązania pomniejszone o należności). Dla zobiektywizowania obu miar, w porównaniach międzynarodowych stosuje się zazwyczaj relacje tych wielkości do PKB.

\section{MIĘDZYNARODOWA POZYCJA INWESTYCYJNA W RELACJI DO PKB}

W ostatnich latach międzynarodowa pozycja inwestycyjna nabiera szczególnego znaczenia jako narzędzie oceny zewnętrznego zrównoważenia gospodarki i jej odporności na sytuacje kryzysowe. Doświadczenia niedawnego kryzysu finansowego uwypukliły bowiem konieczność monitorowania i oceny poziomu nierównowagi makroekonomicznej nie tylko w ujęciu wewnętrznym, lecz także zewnętrznym (Catão, Milesi-Ferretti 2013: 1-37). Okazało się, że dotychczas stosowane zabezpieczenia (m.in. Pakt Stabilności i Wzrostu) były niewystarczające, a kraje o znacznej nierównowadze makroekonomicznej (w tym płatniczej) okazały się bardziej podatne na wahania gospodarcze. Z tego względu w $2011 \mathrm{r}$. zostały wprowadzone nowe procedury makroostrożnościowe (tzw. „,sześciopak”2), których zadaniem jest zapobieganie utracie stabilności gospodarczej oraz przeciwdziałanie narastaniu nadmiernych zakłóceń systemowych. W części prewencyjnej wskazano m.in. szereg wskaźników oceny stabilności zewnętrznej, a poziom MPI jest jednym z nich. Wartość referencyjną ustalono na poziomie -35\% PKB (Commission... 2011), co oznacza, że dopuszczalna jest przewaga zagranicznych pasywów nad aktywami, jednak nie większa niż 35\% PKB. To wprawdzie tylko jeden spośród pięciu mierników oceny nierównowagi zewnętrznej i konkurencyjności gospodarki, lecz umieszczenie go w tym katalogu dowodzi jego znacznej wartości informacyjnej.

2 W skład pakietu wchodzą następujące akty: 1) Rozporządzenie Parlamentu Europejskiego i Rady (UE) nr 1173/2011 z dnia 16 listopada 2011 r. w sprawie skutecznego egzekwowania nadzoru budżetowego w strefie euro; 2) Rozporządzenie Parlamentu Europejskiego i Rady (UE) nr 1174/2011 z dnia 16 listopada 2011 r. w sprawie środków egzekwowania korekty nadmiernych zakłóceń równowagi makroekonomicznej w strefie euro; 3) Rozporządzenie Parlamentu Europejskiego i Rady (UE) nr 1175/2011 z dnia 16 listopada 2011 r. zmieniające rozporządzenie Rady (WE) nr 1466/97 w sprawie wzmocnienia nadzoru pozycji budżetowych oraz nadzoru i koordynacji polityk gospodarczych; 4) Rozporządzenie Parlamentu Europejskiego i Rady (UE) nr 1176/2011 z dnia 16 listopada 2011 r. w sprawie zapobiegania zakłóceniom równowagi makroekonomicznej i ich korygowania; 5) Rozporządzenie Rady (UE) nr 1177/2011 z dnia 8 listopada 2011 r. zmieniające rozporządzenie (WE) nr 1467/97 w sprawie przyspieszenia i wyjaśnienia procedury nadmiernego deficytu; 6) Dyrektywa Rady 2011/85/UE z dnia 8 listopada 2011 r. w sprawie wymogów dla ram budżetowych państw członkowskich. 
$\frac{\sqrt{\frac{\pi}{0}}}{\frac{\pi}{\sqrt{0}}}$

$$
\text { 疍| }
$$

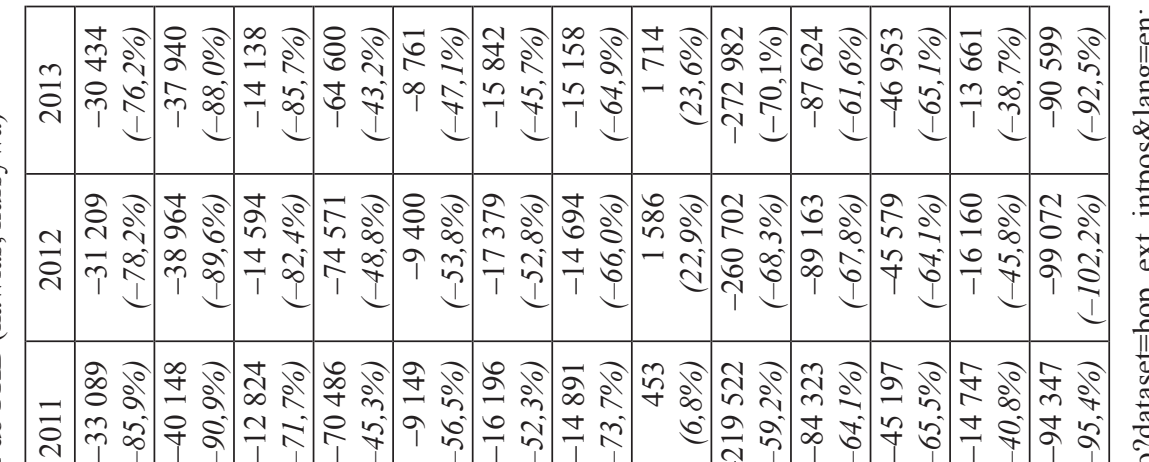

$: \frac{1}{0}$

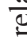

3

స్త్ర

$\stackrel{0}{3}$

三

3

$\frac{0}{4}$

$\frac{\pi}{0}$

光

:三

:

$\frac{\sqrt{2}}{0}$

3

$\stackrel{\circ}{\stackrel{\Xi}{\Xi}}$

疍 㐫

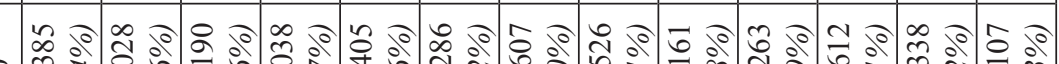

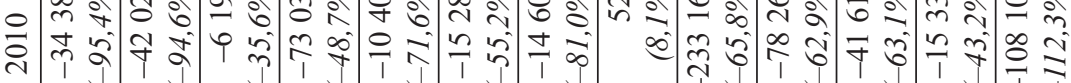

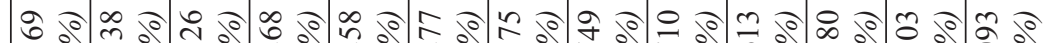

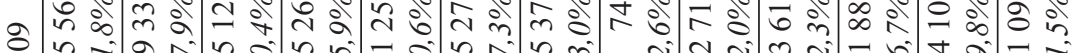

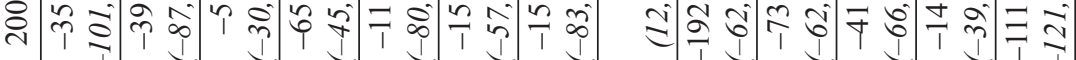

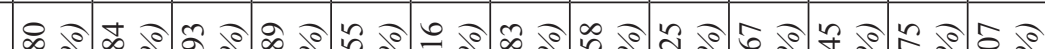

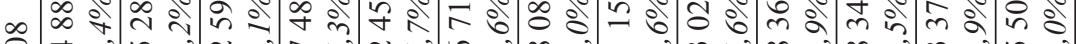

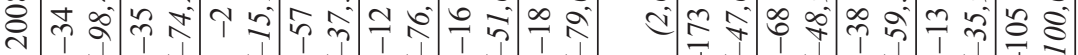

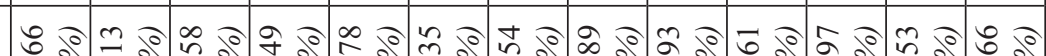
ஓ

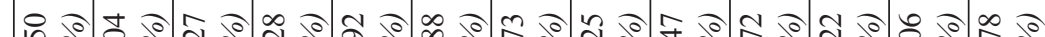

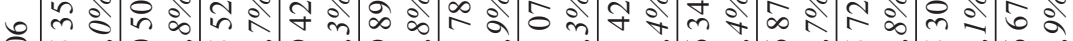

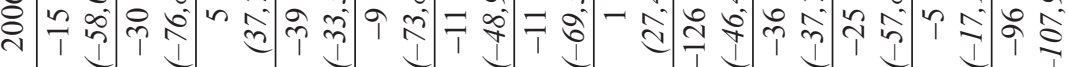

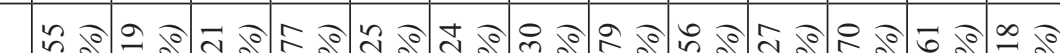

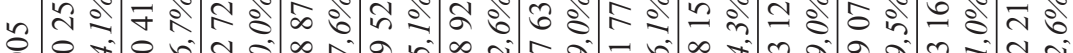

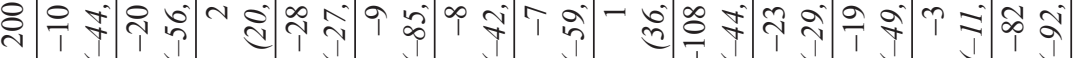

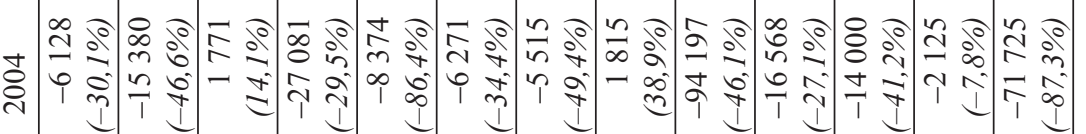
3. 矛.

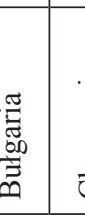

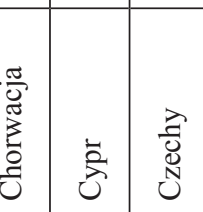

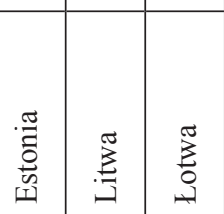

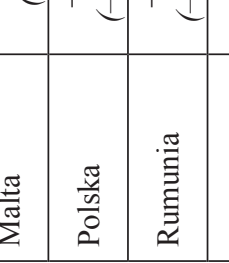

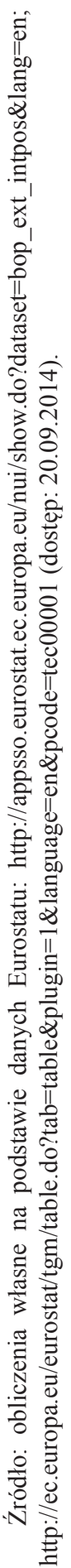


Jak widać $\mathrm{z}$ danych przedstawionych $\mathrm{w}$ tab. 1, w okresie 2004-2013 wszystkie kraje przyjęte do UE w 2005 r. i później, za wyjątkiem Malty, były dłużnikami netto. Co więcej, ich międzynarodowa pozycja inwestycyjna pogorszyła się, tj. państwa zwiększyły skalę finansowania zagranicznego netto. Pogorszenie to było szczególnie szybkie w okresie intensywnego wzrostu PKB badanych krajów, tj. przed kryzysem (przed 2009 r.). Jest to charakterystyczne dla gospodarek otwartych, szybko rozwijających się, które cierpią na niedobór krajowych środków finansujących wzrost. Jednak warto podkreślić, że skala finansowania zagranicznego badanych krajów znacząco przekraczała dopuszczalne progi makroostrożnościowe, co mogło wpływać destabilizująco na ich relacje finansowe z gospodarką globalną i zwiększać podatność na przenoszenie negatywnych bodźców. Problemy te były już wskazywane i analizowane w literaturze (Śliwiński 2008: 158-192; Lane, Milesi-Ferretii 2006: 1-31; Mrzygłód 2011: 68-69).

W początkowej fazie kryzysu gospodarki dodatkowo odczuwały zwiększone zapotrzebowanie na finansowanie zagraniczne. Najdotkliwiej wskaźnik MPI pogorszył się na Węgrzech, w Bułgarii i na Łotwie, ale w tych krajach od $2010 \mathrm{r}$. pozycja inwestycyjna w relacji do PKB zaczęła się poprawiać. Z resztą po $2009 \mathrm{r}$. w większości badanych krajów pozycja inwestycyjna stopniowo poprawiała się (a przynajmniej nie pogarszała). Może to wynikać ze stopniowej spłaty części zobowiązań międzynarodowych oraz pogorszenia atrakcyjności dla kapitału zagranicznego. Wyjątkiem okazała się Polska (która jako jedyny kraj nie zanotowała spadku PKB) i Cypr. Względnie łagodnie kryzys wpłynął na MPI Chorwacji - być może ze względu na jej relatywnie niewysoki poziom integracji w sferze realnej z krajami UE.

Jedynym krajem, który nie tylko nie zwiększył skali zagranicznego finansowania (w ujęciu nominalnym), lecz zmniejszył o połowę wartość wskaźnika MPI do PKB okazała się Estonia. Trzeba jednak podkreślić, że i w jej przypadku poziom zadłużenia był wyższy od dopuszczalnego.

Generalnie, w całym badanym okresie najbardziej zadłużonym krajem były Węgry - ich relacja MPI do PKB kształtowała się w przedziale 87-121,5\%. $\mathrm{Na}$ kolejnych miejscach uplasowały się Chorwacja, Cypr i Bułgaria, choć w początkowych latach badania ich MPI kształtowała się na dużo korzystniejszym poziomie (dla przykładu, w latach 2004-2007 Cypr był wierzycielem, a nie dłużnikiem netto, tj. miał dodatni poziom MPI).

W gospodarkach Słowenii, Cypru, Malty, Słowacji, Słowenii i Estonii na doświadczenia związane z kryzysem finansowym należy nałożyć również zmiany wywołane przystąpieniem do strefy euro. W okresie wstąpienia do strefy euro, w badanych krajach (z wyjątkiem Estonii) MPI pogorszyła się - choć w różnym nasileniu. Największą zmianę odczuł Cypr, który z wierzyciela zmienił się w dłużnika w skali międzynarodowej. Relatywnie niewielką zmianę można było z kolei zaobserwować na Słowacji. 


\section{STRUKTURA MPI W NOWYCH KRAJACH UNII EUROPEJSKIEJ}

Wartość MPI stanowi ważny, ale - jak wskazuje Międzynarodowy Fundusz Walutowy - niepełny miernik oceny sytuacji makroekonomicznej gospodarki. Zgodnie z zaleceniami MFW coraz większą wagę należy przywiązywać nie tylko do samej wartości MPI (brutto i netto) i jej relacji do PKB, lecz także do struktury bilansu (w tym oceny skali niedopasowań walutowych, tzw. currency mismatches). Istotna wydaje się również analiza wpływu rodzaju wykorzystywanych instrumentów na poziom bezpieczeństwa i płynności w gospodarce (Balance of Payments... 2009: 119). Badania naukowe wyraźnie potwierdzają intuicyjne przypuszczenie, że różnice w strukturze aktywów i pasywów zagranicznych mają wpływ na sferę realną gospodarki (Bosworth, Collins 1999: 1-38; De Mello 1999: 133-151; Lane, Milesi-Ferretti 2000: 1-33) czy ryzyko wystąpienia bądź transmisji kryzysu finansowego (Furceri, Guichard, Rusticelli 2011: 1-37). W gospodarkach rozwijających się niewłaściwa struktura zadłużenia (a nie tylko jego wartość) może wpływać zarówno na sferę realną gospodarki i handel (Lane, Milesi-Ferretti 2006: 1-31), jak też zwiększać ryzyko nagłego spowolnienia wpływów kapitałowych z zagranicy (Calvo 2007: 1-21; Calvo, Reinhart 2000: 1-30), co $\mathrm{z}$ kolei może destabilizować procesy wewnętrzne i spowalniać wzrost.

Z punktu widzenia bezpieczeństwa finansowania gospodarki kapitałem zagranicznym najkorzystniejsze wydają się formy długoterminowe o charakterze udziałowym, tj. bezpośrednie inwestycje zagraniczne (Alfaro, Kalemli-Ozcan, Volosovych 2008: 347-368; Sula, Willet 2009: 296-310; Broto, Diaz-Cassou, Erce 2011: 1941-1953). Stanowią one bowiem stabilne źródło kapitału (ich nagłe, masowe wycofanie z kraju jest relatywnie mniej prawdopodobne niż w przypadku kapitału portfelowego), a jednocześnie nie generują istotnego obciążenia dla gospodarki z tytułu odsetek ${ }^{3}$ (tak jak ,pozostałe inwestycje”). Mogą natomiast pozytywnie wpłynąć na wzrost gospodarczy ze względu na transfer wiedzy i technologii oraz wzmacnianie kapitału ludzkiego (przegląd badań prezentuje Ozturk 2007). Dodatkowo, napływ bezpośrednich inwestycji zagranicznych jest uzależniony od sytuacji makroekonomicznej kraju, ale też od jego atrakcyjności inwestycyjnej czy klimatu inwestycyjnego. Władze mają zatem realny wpływ na kształtowanie przyjaznych warunków dla inwestorów bezpośrednich. Za pomocą odpowiednio kształtowanej polityki gospodarczej (np. w zakresie rozwiązań podatkowych) mogą przyciągać pożądane strumienie międzynarodowego kapitału długoterminowego (Wu, Li, Selover 2012: 644645) i wpływać na strukturę MPI zarówno w ujęciu brutto, jak i netto (Furceri, Guichard, Rusticelli 2012: 1-32).

\footnotetext{
${ }^{3}$ Należy jednak podkreślić, że elementem międzynarodowych przepływów kapitału klasyfikowanych jako BIZ są również wewnątrzkorporacyjne pożyczki, które mogą być obciążone odsetkami.
} 

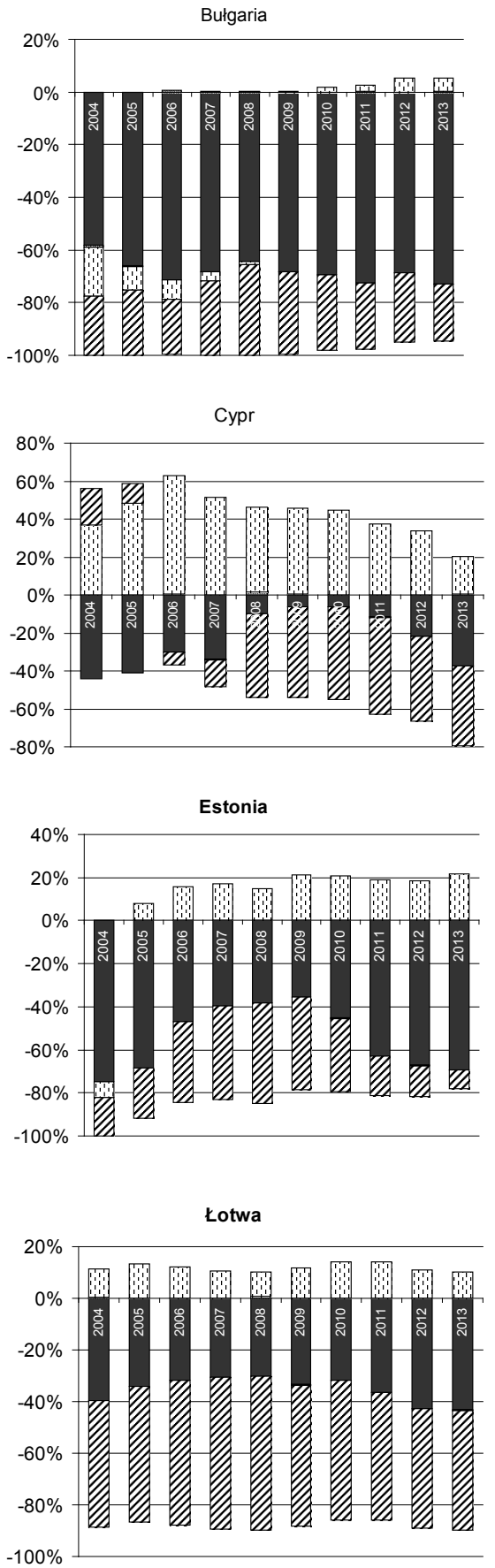
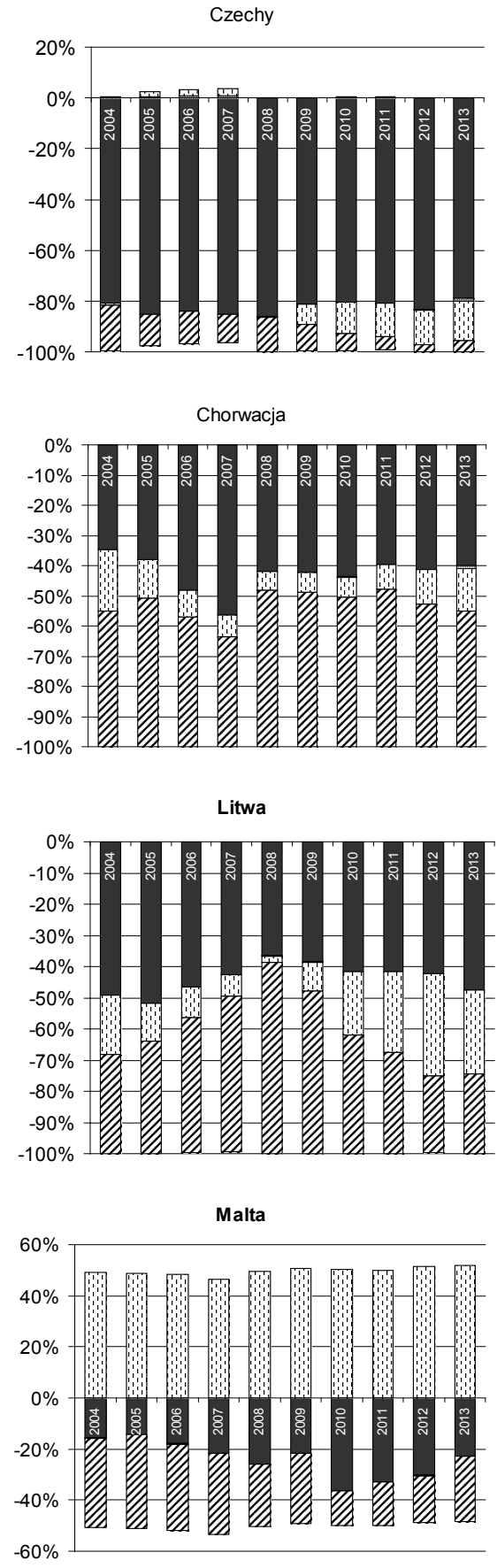


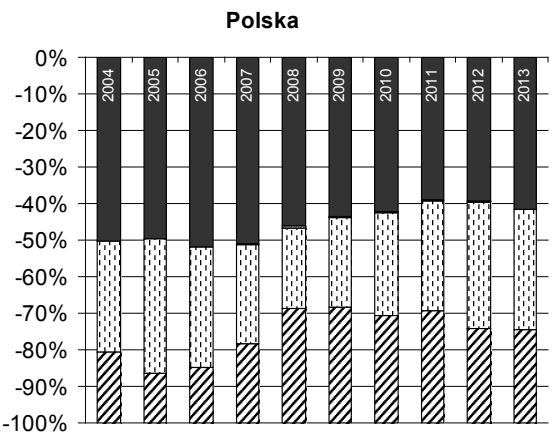

Słowacja
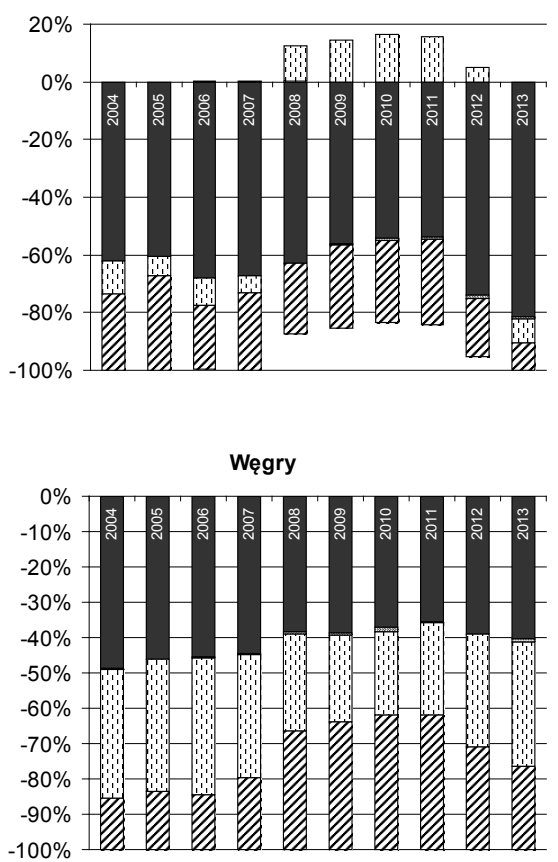
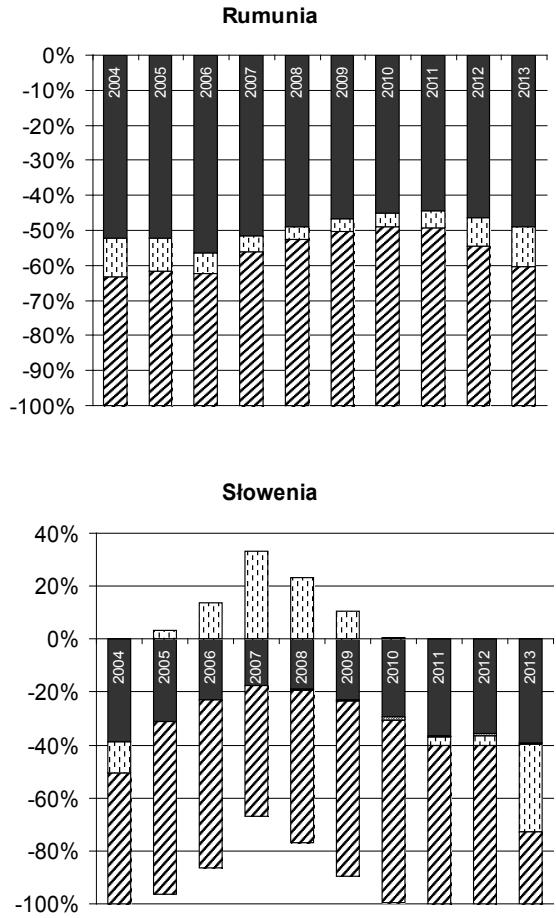

pozostałe inwestycje

Tin inwestycje portfelowe

$\square$ instrumenty pochodne

$\square$ bezpośrednie inwestycje zagraniczne

Rys. 1. Struktura międzynarodowej pozycji inwestycyjnej netto nowych krajów Unii Europejskiej

Źródło: opracowanie własne na podstawie danych Eurostat: http://appsso.eurostat.ec.europa.eu/ nui/show.do?dataset=bop_ext_intpos\&lang=en (dostęp: 20.09.2014).

Jak widać na przedstawionym wykresie (rys. 1), przeciętnie największy udział w kształtowaniu międzynarodowej pozycji inwestycyjnej w większości badanych państw miały bezpośrednie inwestycje zagraniczne. Wszystkie nowe kraje UE były importerami kapitału w tej formie, co nie dziwi ze względu na ich poziom rozwoju gospodarczego oraz niedawne doświadczenia transformacji systemowej. 
Oparcie finansowania zagranicznego gospodarki w znacznym stopniu na BIZ należy ocenić pozytywnie, gdyż daje stabilne podstawy funkcjonowania w oparciu o kapitał długoterminowy.

Drugim ważnym źródłem kapitału z zagranicy były „pozostałe inwestycje”, w tym głównie publiczne oraz prywatne międzynarodowe kredyty i pożyczki. Szczególnie ważną rolę odgrywały one w Chorwacji, na Litwie i Łotwie, jak również w Rumunii i Słowenii, czyli w gospodarkach małych lub niezbyt atrakcyjnych dla inwestorów bezpośrednich. Ze względu na złożoność kategorii „pozostałe inwestycje" trudno jest jednoznacznie ocenić efekty tej formy finansowania. Inaczej bowiem wpłynie na gospodarkę znaczne wykorzystanie zagranicznych pożyczek i kredytów wynikające $\mathrm{z}$ niedostępności innych form finansowania (np. ze względu na niskie oceny ratingowe papierów wartościowych i związane z tym wysokie ryzyko), a inaczej duży udział np. kredytów handlowych, które stanowią immanentną część światowej wymiany towarów i usług oraz obrazują relacje gospodarki z zagranicą w sferze realnej.

Inwestycje portfelowe zajmowały przeciętnie trzecie miejsce w strukturze MPI i jako jedyne wykazywały silną tendencję do generowania nadwyżek kapitałowych (tj. przewagi inwestycji ,wychodzących” nad napływającymi do gospodarki). Taka sytuacja wystąpiła na Cyprze, Łotwie, Malcie, w Estonii, a także w niektórych latach na Słowacji i w Słowenii. Instrumenty pochodne odgrywały we wszystkich krajach rolę jedynie marginalną.

Trudno zauważyć jedną wspólną tendencję zmian w strukturze MPI wywołaną przystąpieniem kraju do strefy euro. Największe podobieństwo można dostrzec w przypadku Słowacji i Słowenii, które na ok. 1-2 lata przed przyjęciem wspólnej waluty znacząco zwiększyły swoją aktywność na międzynarodowym rynku aktywów portfelowych. Można to tłumaczyć motywami ostrożnościowymi, tj. chęcią zmniejszenia ryzyka na wypadek niespodziewanych szoków związanych ze zmianami waluty oraz utratą części rezerw dewizowych. Oba kraje wycofały się z posiadanych zagranicznych aktywów portfelowych w okresie ok. 2-3 lat po wprowadzeniu euro.

\section{ZADŁUŻENIE ZAGRANICZNE W NOWYCH KRAJACH UNII EUROPEJSKIEJ}

Podział transakcji kapitałowych tworzących międzynarodową pozycję inwestycyjną na udziałowe i dłużne pozwala pogłębić analizę nierównowagi zewnętrznej i określić skalę przyszłych obciążeń gospodarki. Dla gospodarki pożyczającej kapitał korzystniejsze wydaje się finansowanie z wykorzystaniem instrumentów udziałowych, ponieważ - jak już wcześniej wspomniano - nie generują dodatkowych kosztów odsetek obciążających przyszłe okresy. Zysk inwestora zależy od efektywności wykorzystania środków. Jeśli bowiem np. 
inwestor zagraniczny zechce wycofać swój kapitał z gospodarki goszczącej, wartość jego wkładu zostanie wyceniona adekwatnie do rentowności funkcjonowania przedsiębiorstwa i jego rynkowej wyceny (ewentualnie również poziomu kursu walutowego). Może się więc okazać, że - w skrajnym przypadku - inwestor poniesie stratę. Tymczasem w przypadku drugiej grupy aktywów dłużnik zawsze musi zwrócić wierzycielowi pożyczoną kwotę powiększoną o z góry określone odsetki ${ }^{4}$.

Z tego względu przydatny w ocenie poziomu zagrożenia z powodu nierównowagi zewnętrznej okazuje się poziom zadłużenia zagranicznego. Wyliczany jest on na podstawie zestawienia transakcji drugiego typu. Najpopularniejszą, a zarazem najczęściej stosowaną przez krajowe i międzynarodowe instytucje finansowe definicją jest tzw. definicja bazowa (core definition). Zgodnie z nią: „Zadłużenie zagraniczne brutto, na koniec danego okresu, jest sumą podjętych i nieuregulowanych zobowiązań rezydentów danego kraju wobec nierezydentów, wynikających z zawartych umów, dotyczących spłat kapitału wraz z odsetkami lub bez, albo spłat odsetek wraz z kapitałem lub bez" (External Debt... 1988).

Warto zauważyć, że definicja ta dotyczy wartości brutto, czyli wyłącznie zobowiązań gospodarki wobec nierezydentów i w takiej formie jest również uwzględniana jako dodatkowy wskaźnik oceny nierównowagi zewnętrznej w prewencyjnej części procedury przeciwdziałania nadmiernym nierównowagom makroekonomicznym (Wajda-Lichy 2013: 321). Tymczasem istotne wydaje się także zbadanie należności gospodarki z tytułu nabycia aktywów dłużnych oraz określenie swoistej „pozycji zadłużenia” (tj. zadłużenia zagranicznego netto) poprzez pomniejszenie pozycji pasywów bilansu o posiadane aktywa. Im większa różnica pomiędzy wartościami brutto i netto, tym lepiej, ponieważ tym większa część długu znajduje „pokrycie” w wierzytelnościach wobec innych gospodarek. Oczywiście dla pogłębienia analizy należałoby porównać strukturę terminową, walutową i procentową należności i zobowiązań. Może to stanowić wskazówkę dla kierunku dalszych badań

Wskaźnik zadłużenia zagranicznego brutto i netto w relacji do PKB badanych gospodarek UE prezentuje tab. 2. Jak widać, wskaźniki zadłużenia zagranicznego netto do PKB kształtowały się na niższym poziomie niż MPI/PKB. Najbardziej zadłużonymi gospodarkami okazały się Chorwacja (w latach 20092013 jej zadłużenie netto wynosiło ok. 60\% PKB) i Węgry (48\% PKB na koniec badanego okresu, przy 66\% PKB w 2009 r.). Co interesujące, Malta i Czechy, a w pierwszych latach badanego okresu również Chorwacja, były wierzycielami gospodarek zagranicznych. Należy to ocenić pozytywnie w kontekście zewnętrznej równowagi makroekonomicznej.

\footnotetext{
${ }^{4}$ Może się jedynie zdarzyć, że odsetki będą naliczane według zerowej stopy procentowej
} 
Tabela 2

Zadłużenie zagraniczne nowych państw Unii Europejskiej (brutto i netto) w relacji do PKB (w \%)

\begin{tabular}{|c|c|c|c|c|c|c|c|c|c|c|c|}
\hline \multicolumn{2}{|c|}{ Wyszczególnienie } & 2004 & 2005 & 2006 & 2007 & 2008 & 2009 & 2010 & 2011 & 2012 & 2013 \\
\hline \multirow{2}{*}{ Bułgaria } & brutto & 62 & 67 & 78 & 94 & 105 & 108 & 103 & 94 & 95 & 93 \\
\hline & netto & 2 & 11 & 16 & 33 & 49 & 50 & 44 & 35 & 29 & 24 \\
\hline \multirow{2}{*}{ Chorwacja } & brutto & 69 & 72 & 75 & 77 & 85 & 101 & 104 & 103 & 103 & 105 \\
\hline & netto & 29 & 33 & 35 & 37 & 46 & 59 & 62 & 61 & 60 & 60 \\
\hline \multirow{2}{*}{ Cypr } & brutto & b.d. & b.d. & 280 & 327 & 447 & 544 & 492 & 468 & 448 & 348 \\
\hline & netto & -23 & -26 & -43 & -20 & -4 & 1 & 8 & 38 & 37 & 42 \\
\hline \multirow{2}{*}{ Czechy } & brutto & b.d. & 41 & 41 & 45 & 45 & 51 & 57 & 57 & 62 & 67 \\
\hline & netto & b.d. & -15 & -10 & -8 & -4 & -1 & 0 & 1 & 0 & -3 \\
\hline \multirow{2}{*}{ Estonia } & brutto & 77 & 86 & 97 & 108 & 117 & 123 & 113 & 94 & 95 & 86 \\
\hline & netto & 18 & 18 & 27 & 35 & 38 & 34 & 23 & 5 & -2 & -6 \\
\hline \multirow{2}{*}{ Litwa } & brutto & 42 & 50 & 60 & 71 & 71 & 84 & 83 & 77 & 75 & 67 \\
\hline & netto & 13 & 16 & 20 & 30 & 35 & 37 & 35 & 32 & 34 & 28 \\
\hline \multirow{2}{*}{ Łotwa } & brutto & 89 & 100 & 114 & 129 & 129 & 156 & 165 & 146 & 136 & 130 \\
\hline & netto & 29 & 36 & 44 & 50 & 57 & 58 & 54 & 47 & 39 & 35 \\
\hline \multirow{2}{*}{ Malta } & brutto & 260 & 357 & 406 & 498 & 538 & 503 & 511 & 503 & 509 & 494 \\
\hline & netto & -85 & -86 & -88 & -85 & -71 & -82 & -161 & -153 & -172 & -115 \\
\hline \multirow{2}{*}{ Polska } & brutto & 47 & 46 & 47 & 51 & 48 & 63 & 67 & 67 & 73 & 71 \\
\hline & netto & 18 & 15 & 18 & 22 & 25 & 34 & 33 & 33 & 37 & 38 \\
\hline \multirow{2}{*}{ Rumunia } & brutto & 36 & 39 & 42 & 47 & 51 & 69 & 75 & 76 & 76 & 68 \\
\hline & netto & 8 & 8 & 11 & 19 & 25 & 35 & 37 & 39 & 40 & 34 \\
\hline \multirow{2}{*}{ Słowacja } & brutto & b.d. & b.d. & b.d. & b.d. & b.d. & 74 & 76 & 78 & 76 & 83 \\
\hline & netto & b.d. & b.d. & b.d. & b.d. & 18 & 22 & 21 & 22 & 22 & 23 \\
\hline \multirow{2}{*}{ Słowenia } & brutto & 56 & 71 & 78 & 101 & 105 & 114 & 115 & 111 & 117 & 113 \\
\hline & netto & -3 & 3 & 11 & 20 & 31 & 37 & 40 & 37 & 42 & 35 \\
\hline \multirow{2}{*}{ Węgry } & brutto & 73 & 81 & 97 & 104 & 116 & 150 & 144 & 133 & 128 & 120 \\
\hline & netto & 34 & 36 & 45 & 50 & 54 & 66 & 61 & 48 & 57 & 48 \\
\hline
\end{tabular}

Źródło: obliczenia własne na podstawie danych Eurostatu: http://appsso.eurostat.ec.europa.eu/ nui/submitViewTableAction.do (dostęp: 25.09.2014). 
Porównanie wskaźnika MPI/PKB i relacji zadłużenia zagranicznego potwierdza względnie bezpieczną strukturę pozycji inwestycyjnej także pozostałych badanych gospodarek, choć warto podkreślić, że udział instrumentów dłużnych zwiększył się. Wykorzystanie instrumentów dłużnych w MPI dla wybranych nowych krajów UE ${ }^{5}$ prezentuje rys. 2.

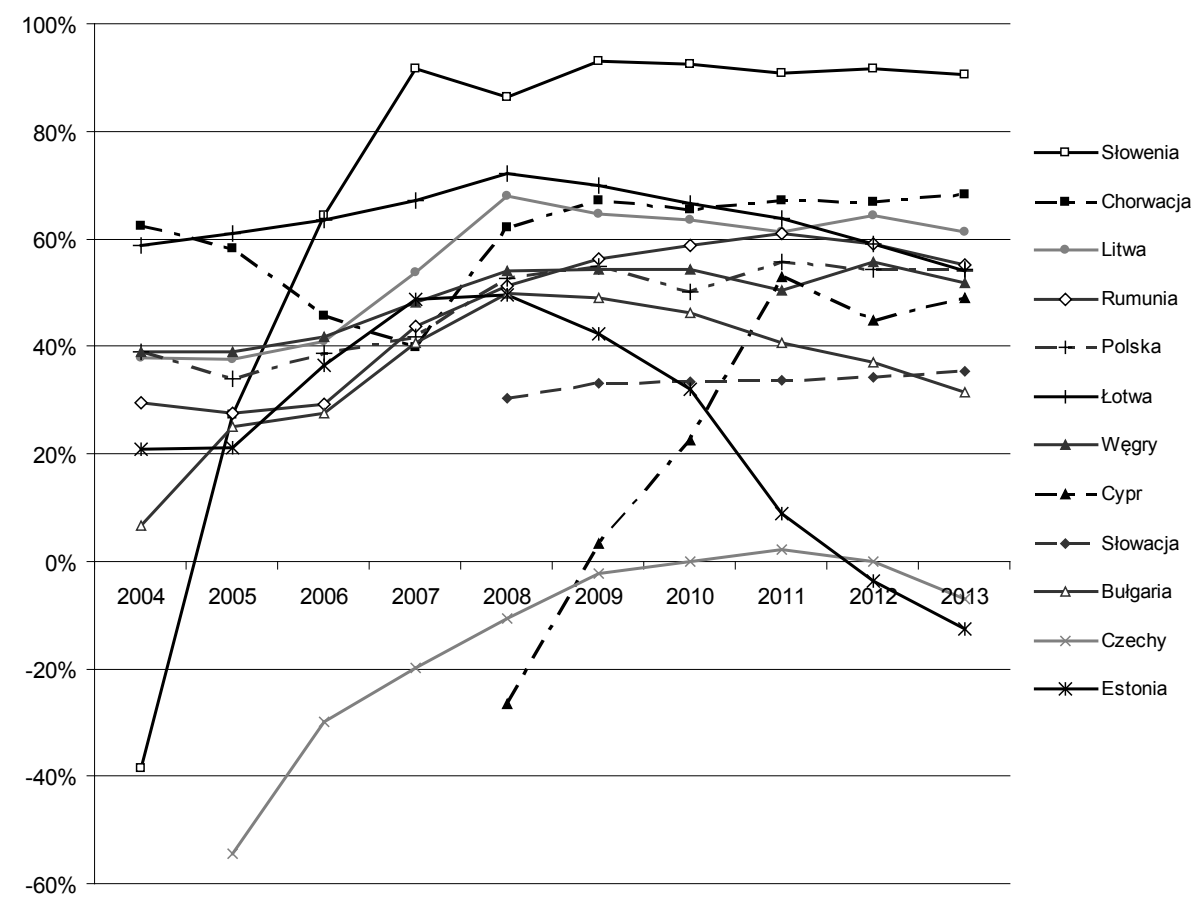

Rys. 2. Relacja zadłużenia zagranicznego do MPI (w ujęciu netto) w wybranych gospodarkach nowych krajów UE

Źródło: obliczenia własne na podstawie danych Eurostatu: http://appsso.eurostat.ec.europa. eu/nui/show.do?dataset=bop_ext_intpos\&lang=en (dostęp: 20.09.2014), http://appsso.eurostat. ec.europa.eu/nui/submitViewTableAction.do (dostęp: 25.09.2014).

W okresie 2004-2008 przeciętny udział instrumentów dłużnych w MPI wzrastał z ok. $20-40 \%$ do ok. 50-70\%, a po 2008 r. utrzymywał się na w miarę stabilnym poziomie. W najgorszej sytuacji znalazła się gospodarka Słowenii, która początkowo w ok. $30 \%$ opierała swoją pozycję inwestycyjną na instrumentach dłużnych, a od 2007 r. skokowo zwiększyła ten udział do ok. 90\%.

5 Obliczenie relacji zadłużenia zagranicznego do MPI dla krajów będących wierzycielami, a nie dłużnikami netto jest nieuzasadnione. Taka sytuacja dotyczy Malty (w całym badanym okresie), a także Cypru (w latach 2004-2007). 


\section{PODSUMOWANIE}

Zagraniczne finansowanie jest naturalną cechą większości gospodarek po transformacji systemowej. Niedobór wewnętrznej akumulacji kapitału powoduje, że skala wykorzystania zagranicznych źródeł finansowania rozwoju krajów Europy Środkowej i Wschodniej, które przystąpiły do UE zwiększała się nie tylko w pierwszych latach przemian, lecz także w kolejnych okresach integracji z gospodarką światową i rynkiem UE. Wynika to ze wzrostu poziomu liberalizacji przepływów kapitałowych i wymiany handlowej oraz z konieczności finansowania ze źródeł zagranicznych narastającego deficytu finansów publicznych.

Nadmierne uzależnienie od zewnętrznych źródeł finansowania może jednak stanowić znaczne zagrożenie dla stabilności makroekonomicznej. Dobitnie ukazał to niedawny kryzys gospodarczy. Wprowadzone (w wyniku jego doświadczeń) w 2011 r. procedury ostrożnościowe, tzw. „sześciopak”, określają dopuszczalną wartość MPI netto na poziomie - $35 \%$ PKB. Tymczasem żadna z badanych gospodarek nowych krajów Unii Europejskiej (za wyjątkiem Malty) nie spełnia tego kryterium, a w najbardziej zadłużonych krajach (tj. na Węgrzech, Cyprze, w Chorwacji i Bułgarii) wskaźnik MPI netto do PKB sięga obecnie ok. $-90 \%$. Dla realnej oceny skali ryzyka wynikającego z nadmiernej nierównowagi warto W związku z tym wykorzystać analizę dodatkowych miar, takich jak struktura MPI oraz zadłużenie zagraniczne. Można bowiem przyjąć, że kapitał długoterminowy (np. bezpośrednie inwestycje zagraniczne) stanowi bezpieczne, stabilne źródła finansowania i im większy jego udział, tym mniejsze zagrożenie wiąże się z samą wartością zadłużenia.

W tym kontekście pozytywnie należy ocenić fakt, iż w większości badanych krajów BIZ odgrywały najważniejszą rolę w strukturze międzynarodowej pozycji inwestycyjnej netto. Na drugim miejscu znalazły się kredyty, pożyczki i pozostałe inwestycje (choć w Słowenii, Rumunii, Chorwacji i na Łotwie to one miały największy udział w MPI). Na kolejnej pozycji znalazły się inwestycje portfelowe i, co ciekawe, jako jedyne generowały dodatnie saldo finansowe - Cypr, Malta, Estonia, Łotwa, a w niektórych latach także Słowacja i Słowenia oraz Czechy i Bułgaria były wierzycielami gospodarek zagranicznych. Transakcje instrumentami pochodnymi miały marginalne znaczenie. Analizując pozycję inwestycyjną kraju (także w kontekście kształtowania się bilansu handlowego i konkurencyjności gospodarki), należy pamiętać o stabilizującej funkcji aktywów rezerwowych (Dąbrowski 2013).

Na uwagę zasługuje też fakt, iż w badanym okresie, a szczególnie od $2008 \mathrm{r}$. znacząco wzrosło przeciętne wykorzystanie instrumentów dłużnych ( $\mathrm{tj}$. takich, w których od wykorzystanego kapitału płaci się odsetki). Generują one znaczne obciążenie finansowe dla gospodarki w przyszłych okresach, stąd zaobserwowany trend wymaga dalszego monitoringu. 
W świetle tendencji do zwiększania skali zagranicznego finansowania zarówno w ujęciu MPI, jak i zadłużenia zagranicznego ważnym kierunkiem dalszych badań wydaje się określenie struktury terminowej i procentowej instrumentów tworzących zarówno stronę aktywów, jak i pasywów obu miar. Nie zawsze bowiem niekorzystne saldo rzeczywiście generuje podwyższone ryzyko niestabilności. Zrównoważenie terminowe oraz w zakresie stóp procentowych po stronie aktywów i pasywów mogłoby zwiększać poziom bezpieczeństwa gospodarek narażonych na zwiększanie nierównowagi zewnętrznej. Takie badania umożliwiłyby również porównanie sytuacji badanych gospodarek. Czynniki wpływające na kształtowanie się skali i struktury zagranicznego finansowania są bowiem tak złożone i różnorodne, że na tym etapie badań trudno o jednoznaczne uogólnienia.

\section{BIBLIOGRAFIA}

Alfaro L., Kalemli-Ozcan S., Volosovych V. (2008), Why Doesn't Capital Flow from Rich to Poor Countries? An Empirical Investigation, "The Review of Economics and Statistics", Vol. 90, No. 2, s. 347-368.

Balance of Payments and International Investment Position Manual (2009), International Monetary Fund, Washington.

Bluedorn J., Duttagupta R., Guajardo J., Topalova P. (2013), Capital Flows are Fickle: Anytime, Anywhere, IMF Working Paper No. 183, s. 1-36.

Bosworth B. P., Collins S. M. (1999), Capital flows to developing economies: Implications for saving and investment, "Brookings Papers on Economic Activity", No. 1, s. 1-38.

Broto C., Diaz-Cassou J., Erce A. (2011), Measuring and explaining the volatility of capital flows to emerging countries, "Journal of Banking and Finance", Vol. 35, Issue 8, s. 1941-1953.

Calvo G. (2007), Crises in emerging market economies: A global perspective, Central Bank of Chile Working Papers, No. 441, s. 1-21.

Calvo G., Reinhart C. (2000), When capital inflows come to a sudden stop: Consequences and policy options, "MPRA Paper", No. 6982, s. 1-30.

Catão L. A. V., Milesi-Ferretti G. M. (2013), External Liabilities and Crises, IMF Working Paper No. 13/113, International Monetary Fund, s. 1-37.

Commission Staff Working Paper. Scoreboard for the surveillance of macroeconomic imbalances: Envisaged initial design (2011), European Commission, Brussels, 8.11.2011, SEC(2011) 1361 final.

Dąbrowski M. A. (2013), Kontrowersje wokół motywów akumulacji rezerw dewizowych przez gospodarki wschodzace, IX Kongres Ekonomistów Polskich, PTE; http://www.pte.pl/kongres/ referaty/D\%C4\%85browski\%20Marek\%20A/D\%C4\%85browski\%20- \%20KONTROWERSJE\%20WOK\%C3\%93\%C5\%81\%20MOTYW\%C3\%93W\%20AKUMULACJI\%20REZERW\%20DEWIZOWYCH\%20PRZEZ\%20GOSPODARKI\%20WSCHODZ\%C4\%84CE. pdf (dostęp: 25.09.2014).

De Mello L. (1999), Foreign direct investment-led growth: Evidence from time series and panel data, "Oxford Economic Papers", No. 51 (1), s. 133-151.

External Debt: Definition, Statistical Coverage and Methodology (1988), BIS, IMF, OECD, World Bank, Paris.

Furceri D., Guichard S., Rusticelli E. (2011), Episodes of large capital inflows and the likelihood of banking and currency crises and sudden stops, "OECD Economics Department. Working Paper", No. 865, s. 1-37. 
Furceri D., Guichard S., Rusticelli E. (2012), Medium-Term Determinants of International Investment Positions: the Role of Structural Policies, "Journal of International Commerce, Economics \& Policy", Vol. 3, Issue 2, s. 1-32.

Kučerová Z. (2009), Measuring Financial Integration in Central Europe Through International Investment Positions, "Eastern European Economics", Vol. 47, Issue 4.

Lane P. R., Milesi-Ferretti G. M. (2000), External Capital Structure: Theory and Evidence, IMF Working Paper No. 00/152, International Monetary Fund, s. 1-33.

Lane P. R., Milesi-Ferretti G. M. (2006), Capital Flows to Central and Eastern Europe, IMF Working Paper No. 06/188, International Monetary Fund, s. 1-31.

Międzynarodowa pozycja inwestycyjna Polski w 2013 roku (2014), Narodowy Bank Polski, Warszawa.

Mrzygłód U. (2011), Procesy integracyjne na rynkach kapitałowych Unii Europejskiej, „Materiały i Studia NBP”, nr 257.

Nakonieczna-Kisiel H. (2011), International Investment Position Versus External Debt, "Folia Oeconomica Stetinensia”, Vol. 10, Issue 2.

Ozturk I. (2007), Foreign Direct Investment-Growth Nexus: A Review of the Recent Literature, "International Journal of Applied Econometrics and Quantitative Studies", No. 4 (2), s. 79-98.

Rozporządzenie Parlamentu Europejskiego i Rady (UE) nr 1176/2011 z dnia 16 listopada 2011 r. w sprawie zapobiegania zakłóceniom równowagi makroekonomicznej i ich korygowania, Dz. U. UE L 306/25.

Śliwiński P. (2008), Zmiany międzynarodowej pozycji inwestycyjnej netto w grupie wybranych krajów Europy Środkowo-Wschodniej oraz Unii Gospodarczej i Walutowej, [w:] E. Najlepszy (red.), Determinanty bilansu płatniczego w krajach europejskich, PWN, Warszawa, s. 158-192.

Sula O., Willet T. D. (2009), The reversibility of different types of capital flows to emerging markets, "Emerging Market Review", Vol. 4, No. 10, s. 296-310.

Wajda-Lichy M. (2013), Procedura nierównowagi makroekonomicznej - rozwiąanie wzmacniajace czy nadmiernie regulujące funkcjonowanie gospodarek Unii Europejskiej, ,Przegląd Zachodniopomorski”, t. 2, nr 3, s. 317-330.

Wu J., Li S., Selover D. D. (2012), Foreign Direct Investment vs. Foreign Portfolio Investment, "Management International Review", Vol. 52, Issue 5, s. 643-670.

\title{
Agnieszka Kłysik-Uryszek
}

\section{INTERNATIONAL INVESTMENT POSITION OF NEW EU MEMBER STATES - THE EXPERIENCE OF INTEGRATION AND CRISIS}

\begin{abstract}
Foreign financing of the economy is one of the important issues discussed in the social and economic debates. On one hand, transition economies, due to the shortage of domestic accumulation, were forced to co-finance their development with foreign capital, on the other hand, excessive involvement of foreign capital may increase the vulnerability to financial crises. In particular, recent financial crisis has shown the sensitivity of the EU economies to financial shocks and highlighted the need to monitoring the scale of external imbalances.

The aim of the article is to examine the level of security of financing economies of the new EU countries with foreign capital, by analyzing the scale and structure of their International Investment Position and Foreign Debt. The study, covering the period 2004-2013, was based on the data derived from Eurostat.
\end{abstract}

Keywords: international investment position, external debt, external imbalances, the new EU member states. 